\title{
Differentiation among Xanthomonas Species by Polyacrylamide Gel Electrophoresis of Soluble Proteins
}

\author{
By T. A. EL-SHARKAWY* AND D. HUISINGH \\ Department of Plant Pathology, N.C. State University, Raleigh, \\ North Carolina 27607, U.S.A.
}

(Accepted for publication 9 July 1971)

\begin{abstract}
SUMMARY
Electrophoretic patterns of esterases, phosphatases, of malate, glucose-6phosphate and $\alpha$-glycerophosphate dehydrogenases, and of other soluble proteins of 69 isolates representing 2 I species of Xanthomonas were determined. Electrophoretic protein patterns were generally identical for all isolates of the same species but dissimilar for different species. Most species showed multiple forms of enzymes. The pattern of $\alpha$-glycerophosphate dehydrogenase was identical in all species and may be genus-specific. Esterases and phosphatases varied widely among species. In most cases, however, taxon-specific patterns, with slight quantitative variations, were evident. No lactate dehydrogenase activity was detected. This technique appears useful in differentiating among Xanthomonas species which until now have been identifiable only by their specific pathogenicity.
\end{abstract}

\section{INTRODUCTION}

Members of the genera Pseudomonas and Xanthomonas constitute more than threequarters of all phytopathogenic bacteria (Stolp, Starr \& Baigent, I965). The xanthomonads are usually recognizable by their distinctive morphological, physiological and biochemical properties (Starr \& Stephens, I964). Species differentiation, however, is not possible using the standard bacteriological tests (Burkholder \& Starr, 1948; Dye, 1962). With the present nomenclature, such differentiation can be accomplished only if the host plant of a given bacterium is known (Starr, 1959).

There has been a growing dissatisfaction with the splitting of Xanthomonas into so many species based solely on host specificity (Stolp et al. 1965) and it has been suggested that most of the xanthomonads should be regarded as one species. Nevertheless, specific pathogenicity was found to be a relatively stable character at the species level (Logan, I960; El-Sharkawy, I964; Schnathorst, I966).

The high degree of similarity among Xanthomonas species, on the basis of their physiological and biochemical properties, was also demonstrated by Adansonian analyses (Colwell \& Liston, I96I $a, b$; Colwell \& Mandel, 1964) and by DNA base composition and hybridization studies (De Ley \& Friedman, 1965; De Ley et al. 1966). It has been suggested on the basis of GC content, that the genus Xanthomonas should be abolished and its members included under Pseudomonas campestris (De Ley, 1968).

Gel electrophoresis has been used as a diagnostic and a taxonomic aid by several workers.

* Present address: Department of Plant Pathology, Cotton Diseases Research Division, Ministry of Agriculture, Orman, Giza, Egypt. 
Protein patterns were found useful for differentiation of various fungi (Durbin, I966; Clare, Flentje \& Atkinson, 1968; Hall, Zentmyer \& Erwin, 1969) of actinomycetes (Gottlieb \& Hepden, 1966), of nematodes (Benton \& Myers, I966; Dickson, Huisingh \& Sasser, 1967) and of bacteria (Cann \& Willox, I965; Lund, I965; Robinson, I966). The diagnostic value of various enzymes has also been investigated in different systems (Paul \& Fottrel, 1961; Bowman, Brubaker, Frischer \& Carson, 1967; Peberdy \& Turner, 1967; Morichi, Sharpe \& Reiter, 1968). The electrophoretic method has been used to a very limited extent with phytopathogenic bacteria (Huisingh \& Durbin, 1965, 1967; El-Sharkawy \& Huisingh, 1968; Gill \& Khare, I968; Smith \& Powell, 1968).

It was thought it would be valuable to apply this technique to members of the Xanthomonas group of phytopathogens and, in experiments reported here, the soluble protein electrophoretic patterns and the enzyme forms of some dehydrogenases, phosphatases, and esterases were determined for 69 strains representing 2I species of Xanthomonas.

\section{METHODS}

Organisms. The following isolates of Xanthomonas species were used: Xanthomonas albilineans PR-235, PR-299 R, E-922, E-I 244; X. alfalfae XA-KX I ; X. begoniae XB $8 ; X$. corylina $\mathrm{XCI} 2 ; X$. campestris XC, XC2, XC I4, XC I05; $X$. dieffenbachiae $\mathrm{XD}, \mathrm{XD} 102 ; X$. fragariae XF I0, XF I8, XF 26, XF 32, XF I02; $X$. hederae XH I; $X$. hyacinthi XH I I0; $X$. incanae XI3; $X$. juglandis XJ, XJ I09; $X$. malvacearum Xм 2, Xм I3, Xм I02, XM I03, Xм I04, Xм I06, Xм I I2, XM I I 5, ZG I, ZG4, XM I2I, XM I2I sm', XM I22, XM I22 sm', b-8, 5-I 3, BR-I, a-76; X. musaccarum XM 2005; $X$. oryzicola XO I, X02; $X$. pelargonii XP I18, XP I 19; $X$. pruni XP, XP 102, XP 167; $X$. phaseoli XP 2, XP I04, XР II6; $X$. phaseoli var. fuscans XP $32 ; X$. translucens var. undulosa XT $8 ; X$. vignicola XVI8; $X$. vesicatoria XVI7, XV27, XV32, XVI10, XVI48, XVI54, XVI8I, XV268, Xv307, xv 309, Xv 319, xv $323 \mathrm{c}, \mathrm{xv} 324$ a, Xv 340. Most of the cultures were obtained from the International Collection of Phytopathogenic Bacteria, University of California at Davis. Other sources were: Department of Plant Pathology, University of California, Berkeley; Department of Botany and Plant Pathology, Oklahoma State University, Stillwater; Department of Bacteriology, University of Puerto Rico, San Juan; Department of Plant Pathology, North Carolina State University at Raleigh; and New Delhi, India.

Cultural and electrophoretic procedures and preparation of cell-free extracts are described in the accompanying paper (El-Sharkawy \& Huisingh, 197I).

Localization of enzymes. Activity of dehydrogenases was located after electrophoresis by immersion of the gels in a reaction mixture containing $10 \mathrm{ml}$. of $0^{\cdot} \mathrm{I} \mathrm{M}$-tris- $\mathrm{HCl}$ buffer, $\mathrm{pH} 8 \cdot 3,8 \mathrm{ml}$. distilled water, $\mathrm{I} 3 \mathrm{mg}$. NAD, $9 \mathrm{mg}$. nitroblue tetrazolium chloride (NBT) in I ml. acetone, $3 \mathrm{mg}$. phenazine methosulphate (PMS) in I ml. acetone, and either $0.134 \mathrm{~g}$. DL-malic acid, $0.025 \mathrm{~g}$. lactic acid, or $0.32 \mathrm{DL}-\alpha$-sodium glycerophosphate. Glucose-6phosphate dehydrogenase was located using a reaction mixture containing $10 \mathrm{ml}$. of $\mathrm{O} \cdot \mathrm{I} \mathrm{M}$ -

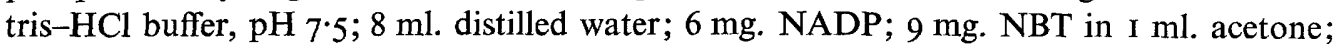
$3 \mathrm{mg}$. PMS in $\mathrm{I} \mathrm{ml}$. acetone; $2 \mathrm{mg}$. $\mathrm{MgCl}_{2}$; and $0.05 \mathrm{~g}$. $\beta$-glucose-6-phosphate. Gels were incubated at $22^{\circ}$ to $25^{\circ}$ in the dark for 5 to 15 min. depending on enzyme activity. Control gels were incubated in the reaction mixtures lacking the substrate. The oxidation of a substrate catalysed by its corresponding dehydrogenase was shown by blue bands of reduced tetrazolium (formazan) in regions containing the dehydrogenase. Prolonged incubation (over $30 \mathrm{~min}$.) resulted in non-specific formazan deposition.

Esterase activity was located by incubating gels in a reaction mixture containing $0.03 \mathrm{~g}$. Fast blue RR salt; $0.5 \mathrm{ml}$. of I \% (w/v) $\alpha$-naphthyl acetate in $50 \%(\mathrm{v} / \mathrm{v})$ acetone; and $24.5 \mathrm{ml}$. 
distilled water after they had been kept in $0 \cdot \mathrm{I}$ M-phosphate buffer, $\mathrm{pH} 7 \cdot 0$, for Io min. Controls were run by replacing the $\alpha$-naphthyl acetate solution with $0.5 \mathrm{ml}$. of $50 \%$ acetone.

Phosphatases were detected by using the following reaction mixture: $0.025 \mathrm{~g}$. Fast blue RR salt; 0.25 g. polyvinyl pyrollidone; 0.025 g. $\alpha$-naphthyl acid phosphate; and three drops each of $10 \% \mathrm{MgCl}_{2}$ and $10 \% \mathrm{MnCl}_{2}$ in $25 \mathrm{ml}$. of buffer. Acetate buffer (0.1 M), $\mathrm{pH} \mathrm{4.6}$, was used for acid phosphatase, and Poulik buffer $(9 \cdot 2 \mathrm{I}$ g. tris, $\mathrm{I} \cdot 05 \mathrm{~g}$. citric acid and $\mathrm{I} 1$. water), $\mathrm{pH} 8 \cdot 8$, for alkaline phosphatase. For the latter, $\mathrm{I} \cdot \mathrm{Og}$. $\mathrm{NaCl}$ was added. In most cases, incubation for $30 \mathrm{~min}$. at $22^{\circ}$ to $25^{\circ}$ in the dark was required.

\section{RESULTS}

General protein patterns. Bacterial species tested gave consistent characteristic patterns of negatively charged proteins which were different for each species. Isolates representing a given Xanthomonas species generally exhibited a very similar characteristic pattern; however, some variations occurred. These variations, among isolates, were largely quantitative, i.e. in the relative density of bands; some minor bands were resolved in extracts of some but not all isolates of a given species, though the general species relationship was always evident (Fig. I). The figures do not include all isolates examined.

Variation was evident among isolates of Xanthomonas albilineans. The four isolates showed three different patterns. Strain E-922 had a pattern which appeared to be intermediate between that of PR-235 and PR-299R on the one hand and E-I244 on the other. Among I8 isolates labelled as $X$. malvacearum $\mathrm{I} 4$ showed practically the same pattern except for some minor bands. The remaining four isolates gave two additional patterns which included XM 104 and XMII 2 in one, and ZG I and ZG 4 in the second. An isolate of X.phaseoli var. fuscans XP 32 had a characteristic pattern different from that exhibited by three isolates of the closely related $X$. phaseoli XP2, XPI04 and XPII6. Minor differences were observed among isolates of $X$. fragariae $\mathrm{XF} 10, \mathrm{XF} 18, \mathrm{XF} 26, \mathrm{XF} 32$ and $\mathrm{XF} 102$ and were confined to the resolution of some very weak bands in some of the five isolates tested. These weak bands were not always resolved in different electrophoretic runs. Similarly, slight variations were also observed among isolates of $X$. campestris and $X$. vesicatoria.

Electrophoretic enzyme patterns. Multiple forms of esterases were detected in most species, although a single band of activity was demonstrated in the two isolates of Xanthomonas dieffenbachiae XD and XD 102 (Fig. 2). Observed variations among isolates of a given species were mainly quantitative and not qualitative. Exceptions to that, however, were found. The four $X$. albilineans isolates showed three different esterase patterns. Twelve of the $14 X$. vesicatoria isolates had qualitatively identical patterns, whereas the remaining two isolates $\mathrm{XV} 16$ and XV 148 were similar to each other and different from the others. Also, isolates XM IO 4 and XM I 12 of X. malvacearum had different esterases from those of ZG I and ZG 4 and these two patterns were different from the characteristic $X$. malvacearum esterases exhibited by the remaining 14 isolates. Otherwise all isolates had taxon-specific esterase patterns.

Acid phosphatases were also of a multiple nature in several xanthomonads. Characteristic taxon-specific patterns were found. Those isolates which deviated from the specific patterns in their esterases similarly showed variations in their acid phosphatases in most cases (Fig. 3). Alkaline phosphatase activities were identical with those of acid phosphatases, but exhibited lower enzymatic activity.

With regard to malate dehydrogenase (Fig. 4), many species had similar patterns but differed in their relative electrophoretic mobility. All species examined showed a multiple form of the enzyme except Xanthomonas albilineans isolates which possessed a single activity band. 
Soluble proteins
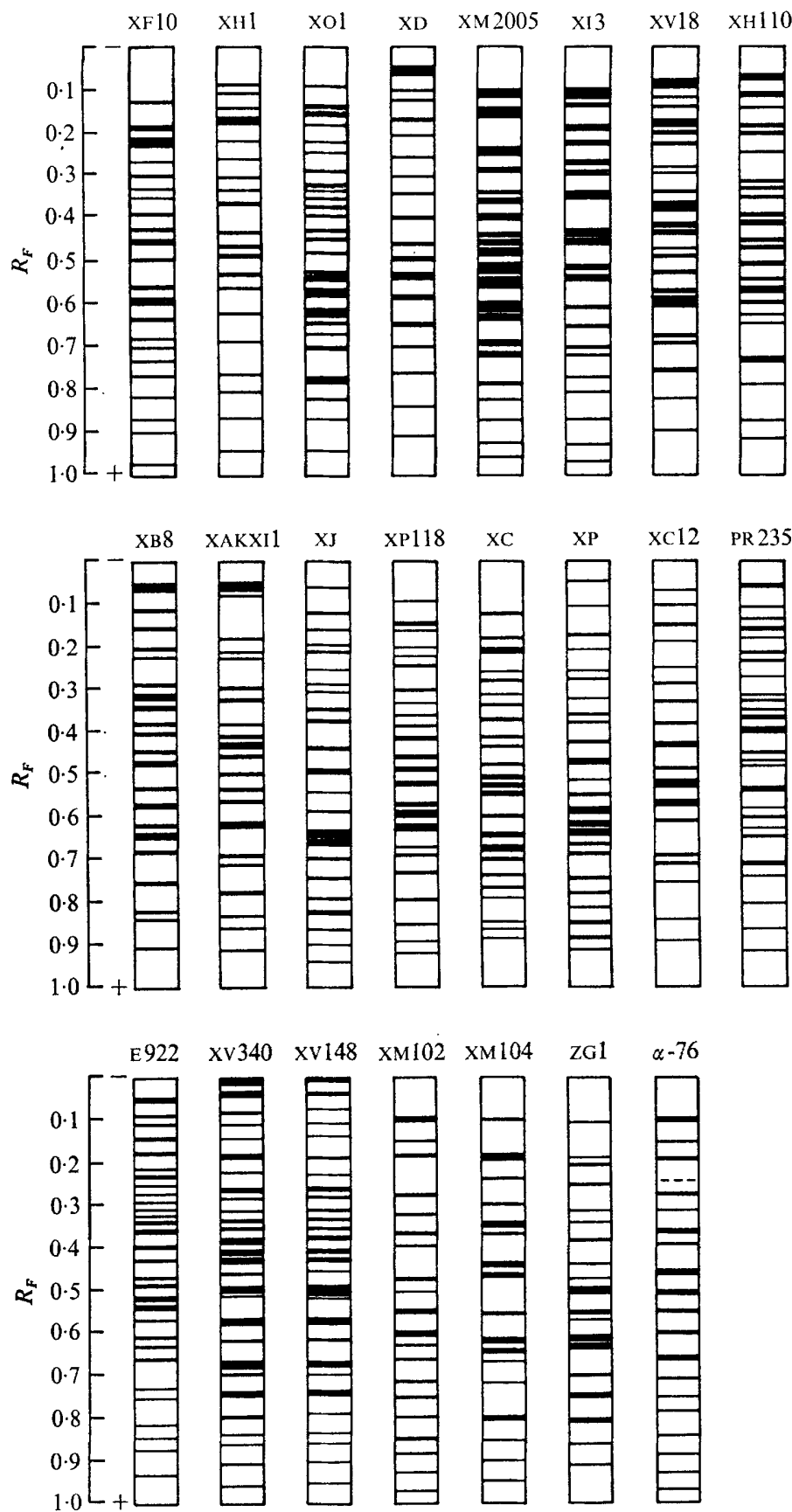

Fig. I. Zymograms of Amido black stained acrylamide gels from various Xanthomonas species. The code is as follows. Row I: XF IO (Xanthomonas fragariae); XH I (X. hederae); XO I ( $X$. oryzicola); XD $(X$. dieffenbachiae); XM 2005 (X. musaccarum); XI3 (X. incanae); XV I8 (X. vignicola); XH IIO $(X$. hyacinthi $)$. Row 2: $\mathrm{XB} 8(X$. begoniae $) ; \operatorname{XAKXI}(X$. alfalfae $) ; \mathrm{XJ}(X . j u g l a n d i s) ; \mathrm{XP} 118(X$. pelargonii $)$; XC $(X$. campestris); XP (X. pruni); XC I2 (X. corylina); PR 235 ( $X$. albilineans). Row 3: E22 (X. albilineans) ; XV340 and XV I48 ( $X$. vesicatoria); XM I02, XM I04, ZG I, $\alpha-76$ ( $X$. malvacearum). 

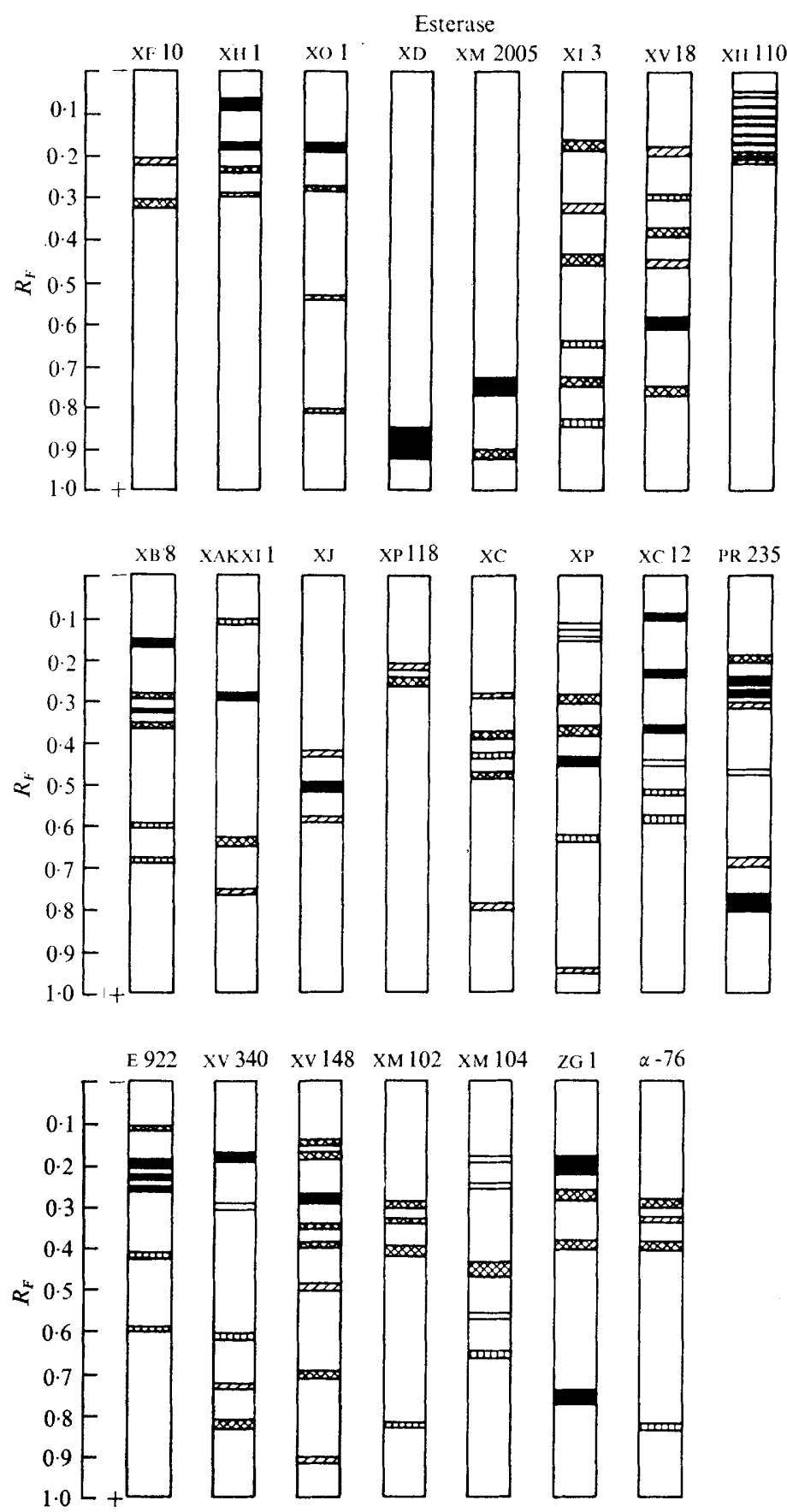

Fig. 2. Zymograms of esterases of representative isolates of various Xanthomonas species. The code is as follows. Row I: XF IO (Xanthomonas fragariae); XH I (X. hederae); Xo I (X. oryzicola); XD (X. dieffenbachiae); XM 2005 (X. musaccarum); XI3 (X. incanae); XVI8 (X. vignicola); XH I 10 (X.hyacinthi); Row 2 : XB 8 (X. begoniae); XAKX I (X.alfalfae); XJ (X.juglandis); XP I I 8 (X.pelargonii); XC (X. campestris); XP (X. pruni); XCI2 (X. corylina); PR 235 (X. albilineans). Row 3: E922 (X. albilineans); XV 340 and XV I48 ( $X$. vesicatoria); XM 102, XM I04, ZG I, $\alpha-76$ ( $X$. malvacearum). 

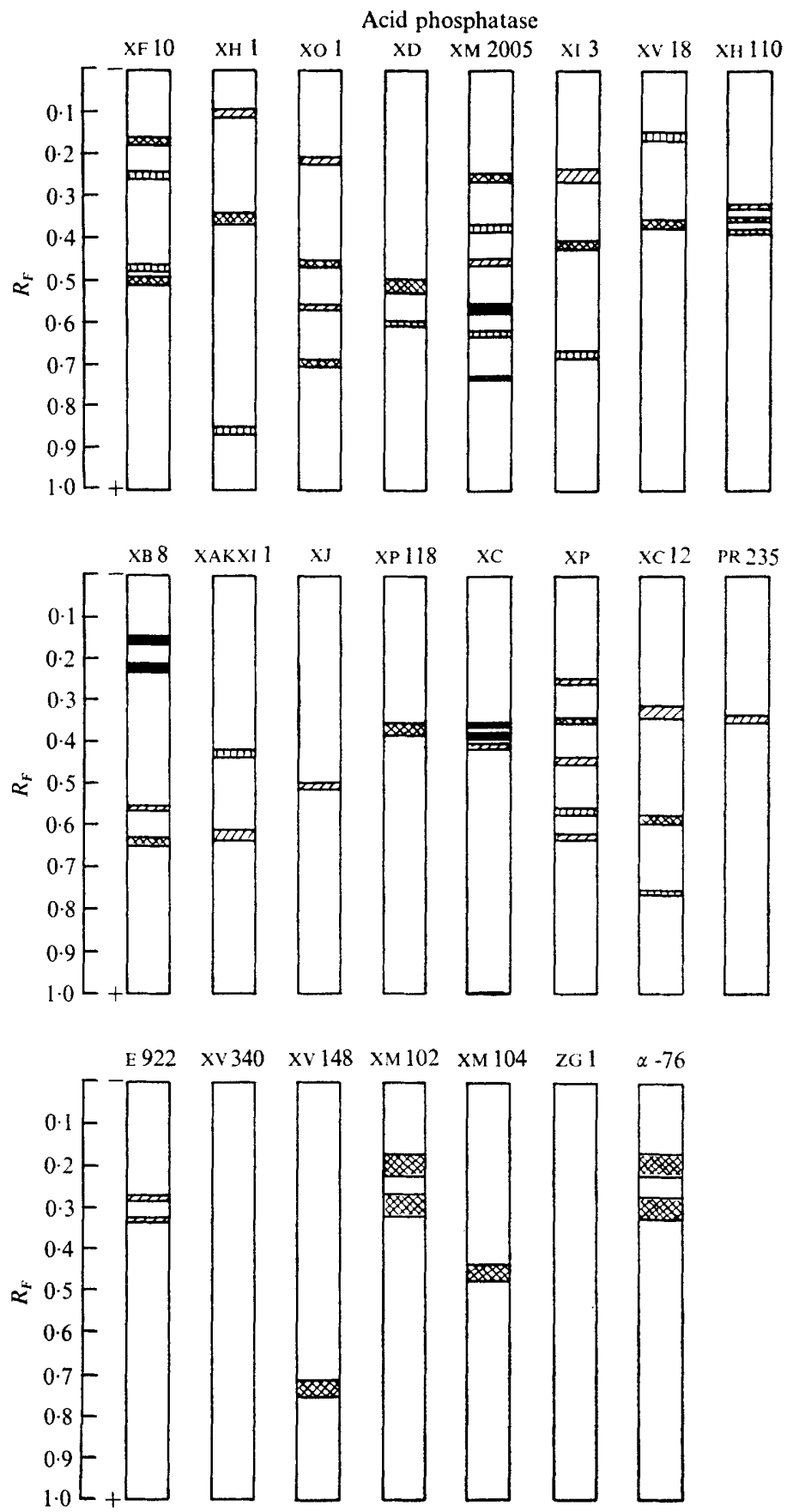

Fig. 3. Zymograms of acid phosphatases of representative isolates of various Xanthomonas species. The code is as follows. Row I: XF IO (Xanthomonas fragariae); XH I (X. hederae); XO I (X. oryzicola); XD $(X$. dieffenbachiae); Xм 2005 (X. musaccarum); XI3 (X. incanae); XVI8 (X. vignicola); XH I IO (X. hyacinthi). Row 2:XB 8 (X.begoniae); XAKXI (X.alfalfae); XJ (X.juglandis); XP I I 8 (X. pelargonii); $\mathrm{XC}(X$. campestris $) ; \mathrm{XP}(X$. pruni $) ; \mathrm{XCI2}(X$. corylina); PR 235 ( $X$. albilineans). Row 3: E922 $(X$. albilineans); XV 340 and XV I48 ( $X$. vesicatoria); XM 102, XM 104, ZG I, $\alpha-76$ ( $X$. malvacearum). (No data for XV 340 and $\mathrm{ZG} \mathrm{I.)}$ 
Malate dehydrogenase
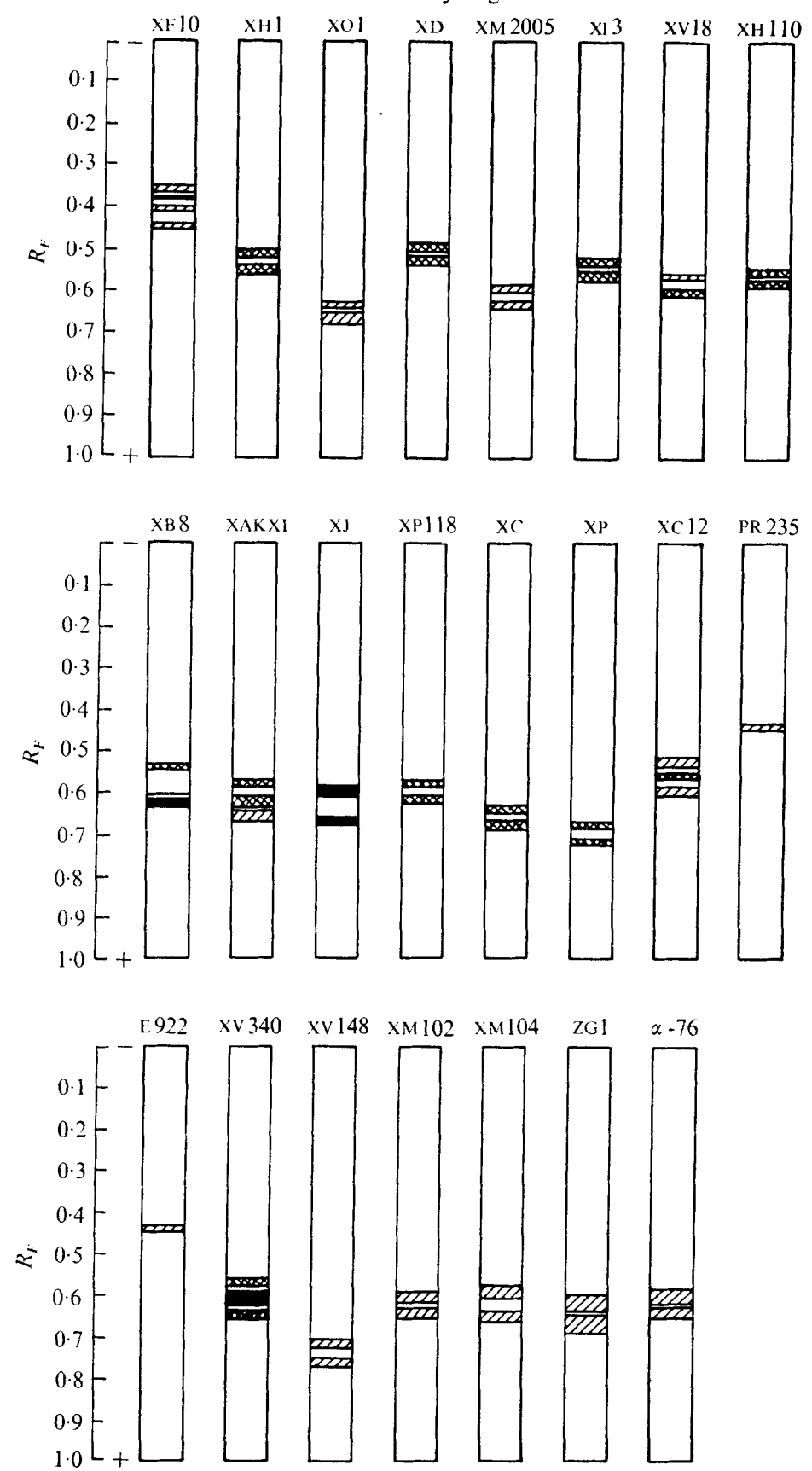

Fig. 4. Zymograms of malate dehydrogenases of representative isolates of various Xanthomonas species. The code is as follows. Row I : XF IO (Xanthomonas fragariae); XH I ( $X$. hederae); XO I $(X$. oryzicola); XD (X. dieffenbachiae); XM 2005 (X. musaccarum); XI 3 (X. incanae); XV I 8 (X. vignicola); XH IIO (X. hyacinthi). Row 2: XB 8 (X. begoniae); XAKXI $(X$. alfalfae); XJ $(X$. juglandis $) ; \mathrm{XPII} 8$ (X.pelargonii); XC (X. campestris); XP (X. pruni); XC I 2 (X. corylina); PR 235 (X. albilineans). Row 3 : E922 (X. albilineans); XV 340 and XV I48 (X. vesicatoria); XM I02, XM I04, ZG I, $\alpha-76$ (X. malvacearum). 
The activity of glucose-6-phosphate dehydrogenase was quite high in all species. The multiple nature of the enzyme was evident with the majority of the species. Only isolates of Xanthomonas albilineans, $X$. pruni and some isolates of $X$. vesicatoria possessed a single band of activity. The majority of species with multiple enzyme forms had similar patterns, not identical, however, in their relative electrophoretic mobilities (Fig. 5). The greatest degree of variation in patterns of these two dehydrogenases, both qualitative and quantitative, was evident among isolates of $X$. vesicatoria.

$\alpha$-Glycerophosphate dehydrogenase provided the same characteristic pattern for all Xanthomonas species examined. The activity was evident as a single band restricted to the top of the separation gel. In no case was enzymatic activity evident within the gel. No lactate dehydrogenase activity was detected in any of the strains examined. The extent of variation in $R_{F}$ values did not exceed \pm 0.0075 unit in different runs under our experimental conditions.

\section{DISCUSSION}

Similarities in the electrophoretic patterns of negatively charged proteins extracted from different isolates of a given xanthomonad may indicate similarity in the metabolism of these organisms. The occurrence of taxon-specific protein patterns may be a reflexion of basic differences related to their highly developed host specificity and may permit a significant advance in our ability to differentiate between these species because, until now, differentiation was not possible by the standard laboratory tests. This may provide a useful approach to studies of speciation and host specificity amongst the xanthomonads.

All xanthomonads tested have active esterase systems. The taxon-specific esterase patterns show that esterase typing can be used in the differentiation and identification of most Xanthomonas species as has been reported with other bacteria (Lund, 1965; Morichi et al. 1968). The specific esterase pattern appears to be significant at the species level, particularly in Xanthomonas malvacearum whose virulent isolates did not behave as one race in pathogenicity studies (El-Sharkawy, 1967). Also, the isolate XM2 was avirulent, yet it had the typical esterase pattern exhibited by the virulent isolates. On the other hand, isolates XM IO4, XM I I 2, ZG I, ZG 4 which were non-pathogenic to cotton did not fit into the taxon-specific pattern. This might indicate that they were either misidentified in the first place or that loss of virulence was accompanied by changes which affected their isozymic patterns.

All species showed phosphatase activity, although to varying degrees in form and intensity. Some species had multiple phosphatases, while others showed a single band of activity. The fact that both acid and alkaline phosphatases were similar may indicate the presence of enzyme forms that can act under both acidic and basic $\mathrm{pH}$ ranges.

The presence of distinct and specific patterns in these hydrolytic enzymes, i.e. esterases and phosphatases, make them of great value in differentiating and identifying species of this group of phytopathogenic bacteria.

On the other hand, the dehydrogenases examined did not differ greatly from one species to another as was evident in both malate and glucose-6-phosphate dehydrogenases. Although the activity of $\alpha$-glycerophosphate dehydrogenase was restricted to the top of the separation gel and was not resolved into separate bands, its presence is an indication of an active glycolytic capability. Such a pattern is probably of significance at the genus level since representatives of other phytobacterial genera lacked it. Whether the enzyme is of such large molecular weight as to interfere with its migration or whether it possesses a low net negative charge should be determined. Only nine of the 69 isolates from the 2I Xanthomonas species differed appreciably from the taxon-specific patterns observed. The reason for this is not 

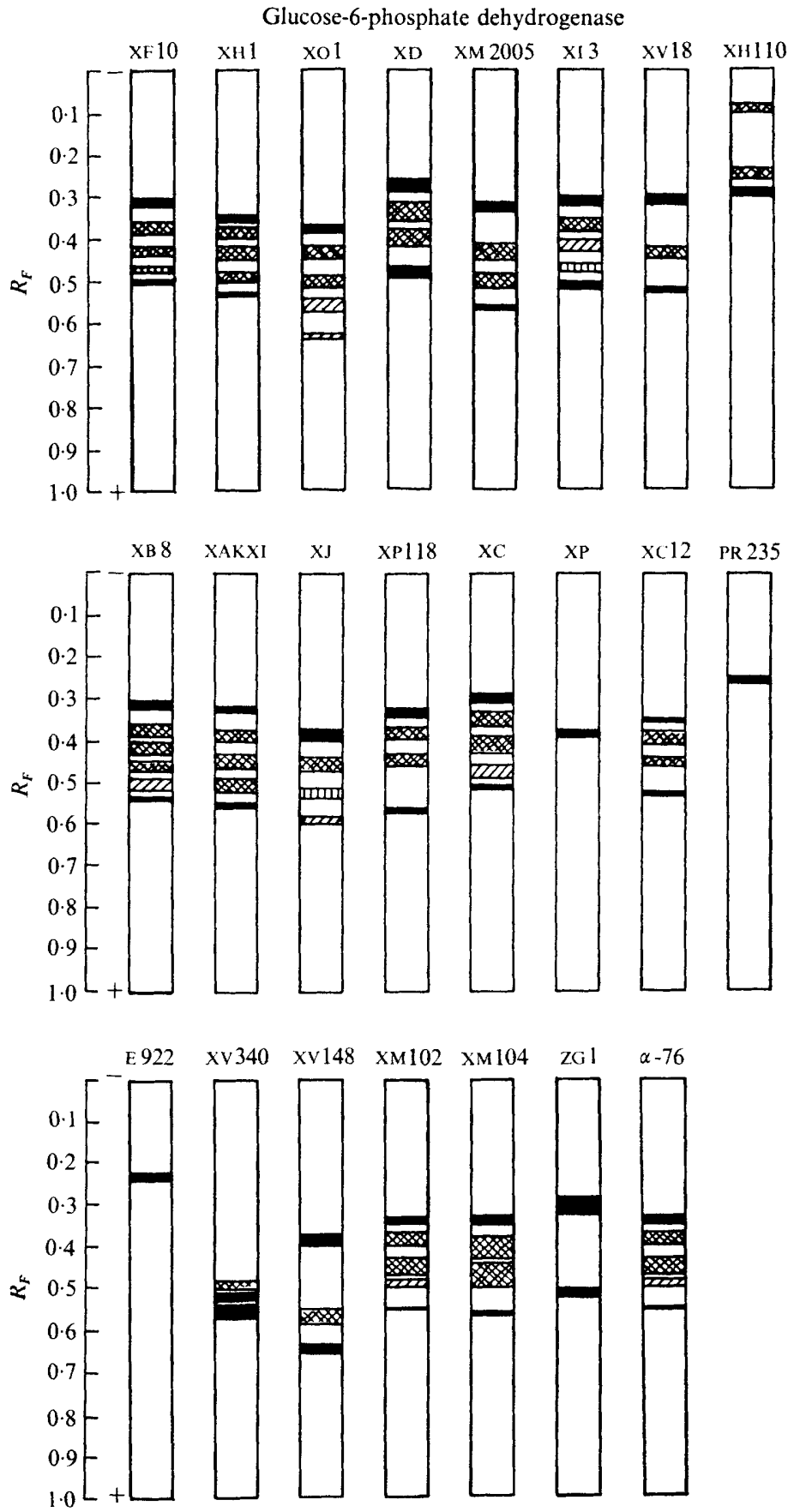

Fig. 5. Zymograms of glucose-6-phosphate dehydrogenases of representative isolates of various Xanthomonas species. The code is as follows. Row I : XF IO (Xanthomonas fragariae); XH I ( $X$. hederae); XO I (X. oryzicola); XD (X. dieffenbachiae); XM 2005 (X. musaccarum); XI 3 (X. incanae); XVI8 (X. vignicola); XH I IO (X. hyacinthi). Row 2: XB 8 (X. begoniae); XAKX I $(X$. alfalfae); XJ $(X$. juglandis); XP I I 8 (X. pelargonii); XC (X. campestris); XP (X. pruni); XC I2 (X. corylina); PR 235 ( $X$. albilineans). Row 3: E922 ( $X$. albilineans); XV340 and XVI48 (X. vesicatoria); XM I02, XM I04, ZG I, ๙-76 (X. malvacearum). 
clear at this time. It may be due to improper identification of the species of the isolate, to mutation or to lysogenic phage infection.

It is concluded that Xanthomonas taxa, separable only on the basis of specific pathogenicity, could be differentiated by their characteristic soluble protein complements. Different taxa had distinct patterns; however, because of the large number of protein bands resolved it might be difficult to depend solely on soluble protein patterns for identification purposes.

Among the enzymes studied, esterases and phosphatases appear to be taxonomically more valuable than malate and glucose-6-phosphate dehydrogenases. It is also concluded, with reservation, that the pattern of $\alpha$-glycerophosphate dehydrogenase is characteristic of the genus.

The high degree of reproducibility makes the gel electrophoretic technique a very useful tool for taxonomic differentiation of phytopathogenic xanthomonads and may help with other groups of pathogens.

The authors wish to thank all those who contributed bacterial cultures used in this investigation, and to acknowledge Mrs Liesellotte Conniff for technical assistance.

This is journal series paper no. 3235 of the North Carolina Agricultural Experiment Station, Raleigh, North Carolina.

\section{REFERENCES}

Benton, A. W. \& MYers R. F. (1966). Esterases, phosphatases and protein patterns of Ditylenchus triformis and Panagrellus redivivus. Nematologica $12,495-600$.

Bowman, J. E., Brubaker, R. R., Frischer, H. \& Carson, P. E. (1967). Characterization of Enterobacteriaceae by starch-gel electrophoresis of glucose-6-phosphate dehydrogenase and phosphogluconate dehydrogenase. Journal of Bacteriology 94, 544-55I.

BuRKholder, W. H. \& STARR, M. P. (1948). The generic and specific characters of phytopathogenic species of Pseudomonas and Xanthomonas. Phytopathology 38, 494-502.

CANN, D. C. \& Willox, M. E. (1965). Analysis of multimolecular enzymes as an aid to the identification of certain rapidly growing mycobacteria, using starch-gel electrophoresis. Journal of Applied Bacteriology 28, I65-173.

Clare, B. G., Flentje, N. T. \& Atkinson, M. R. (1968). Electrophoretic patterns of oxidoxeductases and other proteins as criteria in fungal taxonomy. Australian Journal Biological Science 21, 275-295.

COLWELl, R. R. \& Liston, J. (I96I $a$ ). Taxonomic analysis with the electronic computer of some Xanthomonas and Pseudomonas species. Journal of Bacteriology 82, 913-919.

Colwell, R. R. \& Liston, J. (196r b). Taxonomy of Xanthomonas and Pseudomonas. Nature, London r9r, $617-619$.

Colwell, R. R. \& Mandel, M. (I964). Adansonian analysis and deoxyribonucleic acid base composition of some Gram-negative bacteria. Journal of Bacteriology 87, I4I2-I422.

DE LEY, J. (I968). DNA base composition and hybridization in the taxonomy of phytopathogenic bacteria. Annual Review Phytopathology 6, 63-90.

De Ley, J. \& Friedman, S. (1965). Similarity of Xanthomonas and Pseudomonas deoxyribonucleic acid. Journal of Bacteriology 89, I306-1309.

De Ley, J., Park, I. W., Tijtgat, R. \& Van Ermengem, J. (1966). DNA homology and taxonomy of Pseudomonas and Xanthomonas. Journal of General Microbiology 42, 43-56.

Dickson, D. W., Huisingh, D. \& SASSER, J. N. (I967). A comparison of the electrophoretic protein profiles of Meloidogyne and Heterodera. Phytopathology 57, 468 (abstr.).

Durbin, R. D. (1966). Comparative gel-electrophoretic investigation of the protein patterns of Septoria species. Nature, London 210, II 86-1 187.

DYE, D. W. (I962). The inadequacy of the usual determinative tests for the identification of Xanthomonas spp. New Zealand Journal of Science 5, 393-416.

EL-Sharkawy, T. A. (I964). Pathogenic relationship of some bacterial species of Xanthomonas malvacearum, the cotton bacterial blight pathogen. M.S. Thesis, North Carolina State University, Raleigh, N.C. 
EL-Sharkawy, T. A. (1967). Bacteriophage reactions and pathogenic spectra of Xanthomonas species to cotton. Ph.D. Thesis, North Carolina State University, Raleigh, N.C.

El-Sharkawy, T. A. \& Huisingh, D. (1968). Identification of Xanthomonas species by acrylamide-gel disc electrophoresis of soluble bacterial proteins. Phytopathology 58, 1049 (abstr.).

El-Sharkawy, T. A. \& Huisingh, D. (197I). Electrophoretic analysis of esterases and other soluble proteins from representatives of phytopathogenic bacterial genera. Journal of General Microbiology 68, I49-I 54.

GiLL, H. S. \& KHARE, M. N. (I968). Disc electrophoresis of sonic extracts of five phytopathogenic bacteria. Phytopathology 58, 105I-I052.

Gottlieb, D. \& Hepden, Pamela M. (I966). The electrophoretic movement of proteins from various Streptomyces species as a taxonomic criterion. Journal of General Microbiology 44, 95-104.

Hall, R., Zentmyer, G. A. \& ERwin, D. C. (1969). Approach to taxonomy of Phytophthora through acrylamide-gel electrophoresis of proteins. Phytopathology 59, 770-774.

Huisingh, D. \& Durbin, R. D. (I965). Acrylamide-gel electrophoresis of proteins from Agrobacterium species. Phytopathology 55, 1062 (abstr.).

Huisingh, D. \& Durbin, R. D. (I967). Physical and physiological methods for differentiating among Agrobacterium rhizogenes, $A$. tumefaciens and A. radiobacter. Phytopathology 57, 922-923.

Logan, C. (1960). Host specificity of two Xanthomonas species. Nature, London $\mathbf{1 8 8 , 4 7 9 - 4 8 0 .}$

Lund, B. (1965). A comparison by the use of gel electrophoresis of soluble protein components and esterase enzymes of some group D streptococci. Journal of General Microbiology 40, 4I 3-4I9.

Morichi, T., Sharpe, M. E. \& ReIter, B. (I968). Esterases and other soluble proteins of some lactic acid bacteria. Journal of General Microbiology 53, 405-4I4.

Paul, J. \& Fottrel, P. F. (196I). Molecular variation in similar enzymes from different species. Annals of New York Academy Science 94, 668-677.

Peberdy, J. F. \& Turner, M. (1968). The esterases of Mortierella romanniana in relation to taxonomy. Journal of General Microbiology 51, 303-3I2.

Robinson, K. (I966). An examination of Corynebacterium spp. by gel electrophoresis. Journal of Applied Bacteriology 29, 179-I 84 .

SChNAThorst, W. C. (1966). Unaltered specificity in several Xanthomonads after repeated passage through Phaseolus vulgaris. Phytopathology 56, 58-60.

Sмiтh, J. H. \& Powell, D. (I 968). A disc electrophoretic comparison of protein patterns of Erwinia amylovora with other bacteria, including associated yellow forms. Phytopathology 58, 972-975.

Starr, M. P. (1959). Bacteria as plant pathogens. Annual Review Microbiology 13, 2 I I-238.

StARr, M. P. \& Stephens, W. L. (1964). Pigmentation and taxonomy of the genus Xanthomonas. Journal of Bacteriology 87, 293-302.

Stolp, H., Starr, M. P. \& Baigent, N. L. (1965). Problems in speciation of phytopathogenic pseudomonads and xanthomonads. Annual Review Phytopathology 3, 23 I-264. 